\title{
The Relationship between Lifestyle with the Risk of Diabetes Mellitus in Staff and Lecturers of Universitas Megarezky
}

\author{
Irwansyah Irwansyah $^{1 *}$, Ilcham Syarief Kasim ${ }^{1}$, Bohari Bohari ${ }^{2}$ \\ ${ }^{1}$ Nursing Department, Faculty of Nursing and Midwifery, Universitas Megarezky, City of Makassar, Indonesia; ${ }^{2}$ Nutrition \\ Department, Faculty of Medicine, Universitas Sultan Ageng Tirtayasa, City of Serang, Indonesia
}

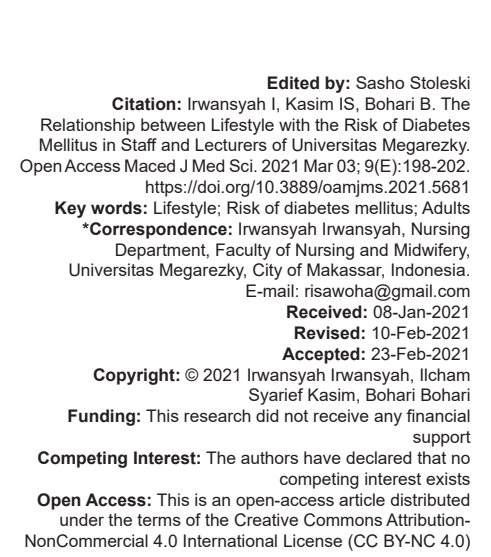

\section{Abstract}

BACKGROUND: An unhealthy lifestyle can lead to high cases of diabetes mellitus, especially in adults and adolescents.

AIM: This study aims to determine the relationship between lifestyle and the risk of diabetes mellitus.

METHODS: This research is a cross-sectional study. The population in this study was 198 with a sample of 91 respondents, obtained using purposive sampling technique.

RESULTS: There were 50 (55\%) respondents who had a good lifestyle and $41(45 \%)$ had a poor lifestyle. There were $53(58 \%)$ respondents who are at risk for diabetes mellitus, $38(42 \%)$ respondents were not at risk, and there is the relationship between lifestyle with diabetes risk with $p=0.00$

CONCLUSION: Staff and lecturers Universitas Megarezky have a higher risk of developing diabetes mellitus. An unhealthy lifestyle is a risk factor for diabetes mellitus in staff and lecturers at Universitas Megarezky.

\section{Introduction}

Diabetes mellitus until today still listed as the cause of death in the world where prevalence is increasing significantly each year was marked by frequent meals (polyphagia), drinking (polydipsia), and urination (polyuria) due to failure the sugar into the cells for processed as energy due to the inability of the pancreas to produce enough insulin or not at all [1]. Globally, an estimated 422 million adults living with diabetes in 2014, compared to 1980, there were only 108 million people. The prevalence of diabetes in general increased from $4.7 \%$ to $8.5 \%$ in the adult population, it reflects an increase in risk factors such as being overweight or obese over the past decade, the prevalence of diabetes has increased more rapidly in low- and middle-income countries than in high-income countries [1]. In the region of Southeast Asia, in 2016, the development of diabetes mellitus cases has reached 96 million people, and $90 \%$ are type 2 diabetes mellitus, but half of these cases are a source of complications that lead to death [2]. International Diabetes Federation (IDF) reveals that in Asia, Indonesia is the country with the $7^{\text {th }}$ diabetes prevalence $(8.5$ million) and predicted an increase in the number of people with diabetes in Indonesia to 14.1 million in 2035 [3].
Factors of risk for diabetes mellitus are a lifestyle including diet or physical activity such as exercise, blood glucose monitoring, and treatment, if not addressed properly, it will be a threat not only a risk but also would be a complication of diabetes mellitus as those found in some diabetes sufferer who fails to make lifestyle changes and monitoring of their disease. Research shows that $20 \%$ of people with diabetes do not monitor blood glucose levels and only $30 \%$ of them do an exercise program so that the cases are very hard pressed and until today is still a global problem [4].

The results of Basic Health Research (Riskesdas) showed the prevalence of diabetes mellitus in Indonesia based on doctor's diagnosis in people aged $\geq 15$ years by the province in 2013 by $1.5 \%$, increasing in 2018 by $2.0 \%$. The highest prevalence of diagnosed diabetes mellitus was in the Jakarta area at $3.4 \%$, and the lowest was in the East Nusa Tenggara area at $0.9 \%$ [3]. Increasing cases of diabetes in Indonesia occurred in various provinces, one of which is the province of South Sulawesi, which ranks fourth as a non-communicable disease with a percentage of $6.65 \%$, and the fifth largest cause of death in South Sulawesi as well as in the city of Makassar diabetes mellitus become one of the dead with the fifth of the top 10 causes, even in 2011, the number of people with diabetes mellitus has reached 5700 and increased in 1300 cases in 2012 or 7000 cases [5]. 
The prevalence of diabetes in South Sulawesi diagnosed by doctors is $1.6 \%$. Diabetes mellitus diagnosed by doctors or based on symptoms was $3.4 \%$. The highest prevalence of diabetes diagnosed by doctors was found in Pinrang Regency (2.8\%), Makassar City $(2.5 \%)$, North Toraja Regency $(2.3 \%)$, and Palopo City $(2.1 \%)$. The highest prevalence of diabetes diagnosed by doctors or based on symptoms was in Tana Toraja Regency (6.1\%), Makassar City (5.3\%), Luwu Regency (5.2\%), and North Luwu Regency (4.0\%). Based on survey data for non-communicable diseases in the P2PL Division of the South Sulawesi Provincial Health Office in 2014 , there were 27,470 new cases of diabetes mellitus, 66,780 old cases with 747 deaths [6].

The major causes of diabetes were overweightedness, obesity, heredity, and lifestyle which include smoking and alcoholism [7]. Personal lifestyle and eating habits which lead to overweightedness and obesity were the primary causes of type 2 diabetes [8]. It is not realized by people who have a busy activity such as office workers or routine teaching staff in front of a computer screen and give lectures in the classrooms, of course, it is risky to metabolic disorders and ultimately will suffer from diabetes. Average lightworkers with less physical activity have high blood glucose levels and suffer from diabetes mellitus [9]. Various routines and bustle of the main reason office workers and teaching staff to have a healthy lifestyle and even health check are very rarely associated with diabetes, it is evident from the results of previous research titled early detection of the risk of diabetes mellitus on teaching staff of Megarezky Makassar in 42 respondents with the result, there were 23 respondents (55\%) who had normal blood sugar levels, 13 respondents (31\%) who were at risk of Type II diabetes mellitus, and there were 6 respondents (14\%) who were identified as suffering from diabetes mellitus.

The high risk of diabetes mellitus cases would be its excuse for researchers, in theory, it is very closely related to lifestyle cannot be separated from office workers. It can be seen in 189 staff and lecturers at Megarezky University, Makassar, on average, had a poor lifestyle, such as when resting, always consume fast food and drinks with high sugar levels and exacerbated by demanding office working hours in staff and lectures for 6 full days starting from 08:00 until 16:01 so that it is considered as a risk factor of diabetes mellitus [10]. The high prevalence of the incidence of diabetes mellitus always increases every year and changes in lifestyle in staff and lecturers of Megarezky University, Makassar, so the objective is to identify the relationship between lifestyle with the risk of diabetes mellitus in staff and lecturers of Universitas Megarezky.

\section{Methods}

This research is a quantitative descriptive correlative design using a cross-sectional study to identify the relationship between lifestyle with the risk of diabetes mellitus in staff and lecturers of Megarezky University, Makassar, with the population in this study which was 198 with a sample of 91 respondents, obtained using purposive sampling technique [11].

The research questionnaire is a questionnaire consisting of the characteristics of the respondent, namely, identity, age, and gender, while in the independent variable, there are 14 questions to measure lifestyle, and in the dependent variable, there are 13 questions to measure the risk factors for diabetes mellitus using a Likert scale both on the independent variable and the dependent variable.

Data analysis, namely, univariate analysis and bivariate analysis to analyze the relationship between independent and dependent variables using the Chisquare test with a significance level of $\alpha<0.05$ using SPSS.

\section{Results}

\section{Characteristics of respondents}

Based on Table 1, the age group of the respondents, namely, in general, was young adults aged $36-45$ years, namely, $34 \%$ and the $26-45$ years age group $33 \%$. Then, the gender of the respondents was dominated by women by $62 \%$. The lifestyle of the respondents is poor, namely, $55 \%$ and most of them are at risk of diabetes mellitus, namely, $58 \%$.

Table 1: Characteristics of respondents on the staff and lecturers of Megarezky University, Makassar

\begin{tabular}{lll}
\hline Characteristics & $\mathrm{n}$ & $\%$ \\
\hline Age & 30 & \\
$26-35$ & 31 & 33 \\
$36-45$ & 20 & 34 \\
$46-55$ & 10 & 22 \\
$56-65$ & & 11 \\
Gender & 35 & 38 \\
$\quad$ Male & 56 & 62 \\
Female & & \\
Lifestyle & 41 & 45.0 \\
$\quad$ Good & 50 & 55 \\
$\quad$ Poor & & \\
The risk of diabetes mellitus & 53 & 58 \\
$\quad$ Risky & 38 & 42 \\
$\quad$ Not at risk & 91 & 100 \\
$\quad$ Total & & \\
\hline
\end{tabular}

\section{Relationship between lifestyles with the risk of diabetes mellitus}

Table 2 shows that there is a significant relationship between lifestyle and the risk of diabetes mellitus with a value of $p=0.00(p<0.05)$. The risk of diabetes mellitus was found more in respondents with a poor lifestyle by $45 \%$. 
Table 2: Relationship between lifestyles with the risk of diabetes mellitus on the staff and lecturers of Megarezky University, Makassar

\begin{tabular}{|c|c|c|c|c|c|c|c|}
\hline \multirow[t]{3}{*}{ Lifestyle } & \multicolumn{7}{|c|}{ Risk of diabetes mellitus } \\
\hline & \multicolumn{2}{|c|}{ Risky } & \multicolumn{2}{|c|}{ Not at risk } & \multicolumn{2}{|c|}{ Total } & \multirow[t]{2}{*}{ p-value(Pearson) } \\
\hline & $\mathrm{n}$ & $\%$ & $\mathrm{n}$ & $\%$ & $\mathrm{n}$ & $\%$ & \\
\hline Poor & 41 & 45 & 0 & 0 & 41 & 45 & 0,00 \\
\hline Good & 12 & 13 & 38 & 42 & 50 & 55 & \\
\hline Total & 53 & 58 & 38 & 42 & 91 & 100,0 & \\
\hline
\end{tabular}

\section{Discussion}

Diabetes is a non-communicable disease but considered a dangerous one, and in the past few years, diabetes mellitus has killed millions of people worldwide with complications that are not handled properly. Several factors are related to the risk of diabetes mellitus which were age, gender, obesity, history of heart disease, hypertension, and cholesterol, and one of them is a poor lifestyle be the core risk factor, it is still poorly understood by various groups, including those in the educational environment, which are educators and staff who have a sufficient understanding of it.

Based on this research, it is inversely as the results of the univariate analysis of the lifestyles associated with diet and physical activity. The poor lifestyle of this research is based on the evaluation of the questionnaires of the two items, which had a bad rate. The first on the diet of some respondents did not pay attention to diet, for example, in terms of frequency, the frequency of respondents has eaten more than 3 times a day with the lack of healthy food, for example, by eating foods that contain coconut milk and high cholesterol. Aside from that, it can be seen almost every day the staff and faculty at Megarezky University always consume fried foods and carbonated beverages so that it can be worth the poor health and not just as the risk of diabetes mellitus, but it could be at risk for heart disease or cancer [12].

The second is a physical activity that generally the staff and lecturers of Megarezky University have a monotonous physical activity with office hours starting from $8 \mathrm{am}$ to $4 \mathrm{pm}$ during the 6 days of work hours. It became one of the diabetes risks because no physical activity at all, in general, staff and faculty just sitting in an air-conditioned room, and on Sundays, they rarely do sports because they gather with family, recreation, and some respondents chose to go to entertainment place to spend vacation time, it is at risk of diabetes mellitus due to physical inactivity affects the work of insulin as a bridge entry of sugar into cells, so that if it prolonged, it can become diabetes mellitus [13].

The risk of diabetes mellitus is related to blood sugar levels, obesity, heredity, age, and lifestyle, and even this study reports that of 91 respondents, there were $53(58 \%)$ respondents who were similar from the research we previously did which detect blood sugar levels of respondents with test $C$ peptide 2019 with 43 respondents and $40 \%$ of respondents at risk [14]. The high prevalence of diabetes mellitus risk is related to several factors. Everyone has the same potential to be at risk for diabetes mellitus, although there is some statement said that diabetes mellitus is a hereditary disease or genetic factors [15]. However, not all people with Type II diabetes mellitus have a hereditary history but are influenced by several factors such as age, gender, obesity, physical activity, and stress [16].

In this study, gender as a risk factor is directly related to the risk of diabetes mellitus, this study was dominated by $56(62 \%)$ women and $35(38 \%)$ men. No research describes the cause of high blood sugar levels are influenced by gender although biological or anatomical differences, but people with diabetes mellitus dominated by men or women but the case could be considered almost the same, the statement of gender as a risk factor is justified if it is always associated with the lifestyle of most men generally have a worse lifestyle than women, some studies reveal some lifestyle as a risk factor for Type 2 diabetes mellitus, such as diet, physical exercise, stress, smoking, and consuming excessive alcohol and even men usually very rarely have their health checked without any serious signs and symptoms. The percentage of people with diabetes is dominated by women was associated with less physical activity than men [17]. Diabetes mellitus always associated with hormonal related to the reproductive system that women will experience menopause as the main cause of the accumulation of fat so it is at risk of Type 2 diabetes mellitus [18], [19].

Based on Table 2, the relationship between lifestyle with the risk of diabetes mellitus, there were 41 respondents $(45 \%)$ who had a poor lifestyle with the risk of diabetes mellitus and no respondents who have a bad lifestyle are not at risk, while the respondents who have a good lifestyle are at risk as many as $12(13 \%)$ respondents and $38(42 \%)$ respondents who have a good lifestyle are not at risk. Based on the results of the Chi-square test, the relationship between lifestyle with the risk of diabetes mellitus with $p=0.00$, because $p<\alpha=0.05$, which means that there is a relationship between lifestyle with the risk of diabetes mellitus.

In theory, lifestyle was associated with diet, physical activity, and considered as a risk factor for diabetes mellitus. Lifestyle is one of the causes of diabetes mellitus, such as overeating or consuming foods high in sugar, so that there is no balance between sugar and insulin in the blood, then it causes a buildup of sugar outside the cells that is not used as energy and becomes the risk of type II diabetes mellitus [20].

Some risk factors that are close to a lifestyle are obesity caused by improper diet and lack of exercise so that the accumulation of excess calories can ultimately lead to obesity, which is assessed from the circumference of the abdomen, arms, or ideal weight based on body mass index. Obesity is a cause of reduced insulin sensitivity, which reduces the number of insulin receptors that can work in cells, 
including muscle and fat tissue. It is called peripheral insulin resistance. Obesity also impairs the ability of beta-cells to release insulin when an increase in glucose, so it can be concluded that obesity may cause the response of pancreatic beta-cells to increase blood glucose is reduced, in addition to the insulin receptors on cells throughout the body including the muscles are reduced number and activeness (less sensitive) [21]. The best treatment for diabetes is prevention [22]. Prevention of diabetes can be accomplished through a $7 \%$ weight loss through intensive lifestyle interventions that include caloric reduction and approximately $30 \mathrm{~min}$ of daily moderate physical activity [22].

Most of the respondents have high blood sugar levels with a statement that they consume excessive calories more than 3 times a day, where lecturers and staff of Megarezky University did not have enough time to do physical activity, and at holiday, they still consume foods that are high in calories and sugar and do not exercise because they use a day off to gather with family and recreation. Even some experts claim that the rise in cases of diabetes mellitus is caused by risk factors that cannot be changed include age, ethnicity, family, and diabetes mellitus gestational whereas risk factors can be changed such as obesity, physical inactivity, hypertension, and an unhealthy diet or lifestyle [23].

Revealed by the IDF 2017, one risk factor for Type II diabetes mellitus is a lifestyle associated with less physical activity because they do not have the time to exercise so that it can be used as the basis for determining the risk of diabetes mellitus [24]. However, based on the bivariate analysis in this study, there were 12 respondents with a good lifestyle, but at risk of diabetes mellitus, this is due to several risk factors that cannot be changed, such as having a family history of diabetes mellitus, and among these respondents had a history of gestational diabetes as well as other factors as the support that the average age of the respondents included in the category of risk of diabetes mellitus. Lifestyle intervention programs promoting healthy diets, physical activity, and modest body weight reductions can prevent or delay the onset of diabetes among high-risk population [25].

The implication of this research is that to protect lecturers and staff from diseases specifically diabetes mellitus, Universitas Megarezky headers need to make and implement policies on a healthy lifestyle and provide nutrition and health counseling rooms that can be utilized by lecturers and staff.

\section{Conclusion}

A poor lifestyle had a significant relationship with the risk of diabetes mellitus. Lifestyles that are considered a poor lifestyle, namely the amount of excess energy intake, the habit of consuming foods with high energy density (high fat and sugar, less fiber), wrong food processing techniques (using lots of oil, sugar, and thick coconut milk), and lack of physical activity due to technological advances and the availability of various facilities that provide various conveniences for the majority of the community. It is expected that the entire staff and lecturers to improve their lifestyle especially those related to diet and physical activity to reduce the risk of diabetes mellitus.

\section{References}

1. World Health Organization. Diabetes. Geneva: World Health Organization; 2020. Available from: https://www.who.int/newsroom/fact-sheets/detail/diabetes. [last accessed on 2021 Feb 10].

2. Saeedi P, Petersohn I, Salpea P, Malanda B, Karuranga S, Unwin $\mathrm{N}$, et al. Global and regional diabetes prevalence estimates for 2019 and projections for 2030 and 2045: Results from the international diabetes federation diabetes atlas, $9^{\text {th }}$ edition. Diabetes Res Clin Pract. 2019;157:107843. https://doi.org/10.1016/j.diabres.2019.107843 PMid:31518657

3. Kemenkes RI. Riset Kesehatan Dasar (RISKESDAS). Balitbang Kemenkes RI; 2013. https://doi.org/10.32922/jkp.v8i2

4. Raoufi AM, Tang X, Jing Z, Zhang X, Xu Q, Zhou C. Blood glucose monitoring and its determinants in diabetic patients: A cross-sectional study in Shandong, China. Diabetes Ther. 2018;9(5):2055-66. https://doi.org/10.1007/s13300-018-0499-9

5. Dinas Kesehatan Provinsi Sulawesi Selatan. "Report: Number of People with Diabetes Mellitus. Makassar: Dinas Kesehatan Provinsi Sulawesi Selatan; 2013. https://doi.org/10.31227/osf. io/xdhk9

6. Dinas Kesehatan Provinsi Sulawesi Selatan. Health Profile of South Sulawesi Province in 2015. Dinas Kesehatan Provinsi Sulawesi Selatan; 2015. https://doi.org/10.31227/osf.io/xdhk9

7. Asiimwe D, Mauti GO, Kiconco R. Prevalence and risk factors associated with Type 2 diabetes in elderly patients aged 45-80 years at Kanungu district. J Diabetes Res 2020;2020:5152146. https://doi.org/10.1155/2020/5152146

8. Bahendeka S, Wesonga R, Mutungi G, Muwonge J, Neema S, Guwatudde D. Prevalence and correlates of diabetes mellitus in Uganda: A population-based national survey. Trop Med Int Health. 2016;21(3):405-16. https://doi.org/10.1111/tmi.12663 PMid:26729021

9. Nyenwe EA, Odia OJ, Ihekwaba AE, Ojule A, Babatunde S. Type 2 diabetes in adult Nigerians: A study of its prevalence and risk factors in Port Harcourt, Nigeria. Diabetes Res Clin Pract. 2003;62(3):177-85. https://doi.org/10.1016/j. diabres.2003.07.002

PMid:14625132

10. Alfiani N, Yulifah R, Sutriningsih A. The Relationship between knowledge about diabetes mellitus and lifestyle of patients having diabetes mellitus at Dr. Soepraoen Region II hospital, Malang. Nurs News 2017;2(2):2.

11. Salemba Medika. Nursalam, Nursing Research Methodology: A Practical Approach. Jakarta: Salemba Medika; 2016.

12. Martín-Timón I, Sevillano-Collantes C, Segura-Galindo A, del Cañizo-Gómez FJ. Type 2 diabetes and cardiovascular disease: Have all risk factors the same strength? World J Diabetes. 2014;5(4):444-70. https://doi.org/10.4239/wjd.v5.i4.444 PMid:25126392 
13. Colberg SR, Sigal RJ, Fernhall B, Regensteiner JG, Blissmer BJ, Rubin RR, et al. Exercise and Type 2 diabetes. Diabetes Care. 2010;33(12):e147-67. https://doi.org/10.2337/dc10-9990

14. Kesehatan JI, Husada S. Early detection of diabetes mellitus risk in stikes megarezky makassar teaching staff. Juni. 2020;11(1):540-7. https://doi.org/10.35816/jiskh.v11i1.343

15. Asamoah EA, et al. Heritability and genetics of Type 2 diabetes mellitus in Sub-Saharan Africa: A systematic review and metaanalysis. J Diabetes Res. 2020;2020:3198671. https://doi. org/10.1155/2020/3198671

16. Wu $\mathrm{Y}$, Ding $\mathrm{Y}$, Tanaka $\mathrm{Y}$, Zhang $\mathrm{W}$. Risk factors contributing to Type 2 diabetes and recent advances in the treatment and prevention. Int $\mathrm{J}$ Med Sci. 2014;11(11):1185-200. https://doi.org/10.7150/ijms.10001 PMid:25249787

17. Haghdoost AA, Rezazadeh-Kermani $M$, Sadghirad $B$ Baradaran HR. Prevalence of Type 2 diabetes in the Islamic Republic of Iran: systematic review and meta-analysis. East Mediterr Health J. 2009;15(3):591-9. https://doi. org/10.26719/2009.15.3.591 PMid: 19731775

18. Wang C, Zhang W, Wang Y, Wan H, Chen Y, Xia F, et al. Novel associations between sex hormones and diabetic vascular complications in men and postmenopausal women: A crosssectional study. Cardiovasc Diabetol. 2019;18(1):97. https://doi. org/10.1186/s12933-019-0901-6

19. Nusrianto R, Ayundini G, Kristanti M, Astrella C, Amalina N Muhadi, et al. Visceral adiposity index and lipid accumulation product as a predictor of Type 2 diabetes mellitus: The Bogor cohort study of non-communicable diseases risk factors. Diabetes Res Clin Pract 2019;155:107798. https://doi. org/10.1016/j.diabres.2019.107798

20. Guo X, Li H, Xu H, Woo S, Dong H, Lu F, et al. Glycolysis in the control of blood glucose homeostasis. Acta Pharm Sin B. 2012;2(4):358-67.

21. Damayanti S. Diabetes Melitus dan Pelaksanaan Keperawatan. Yogyakarta: Nuha Medika; 2017.

22. Barnes AS. The epidemic of obesity and diabetes. Tex Heart Inst J. 2011;38(2):142-4

PMid:21494521

23. Kurniawaty E, Yanita B. Risk factors related Type 2 diabetes mellitus evidance. J Majority. 2016;5(2):2.

24. Israel Defense Forces. Education and Integrated Care Stream: Achieving Success through Integrated Care. Diabetes Voice Global Perspective on Diabetes. Israel: Israel Defense Forces; 2017.

25. Galaviz KI, Narayan KM, Lobelo F, Weber MB. Lifestyle and the prevention of Type 2 diabetes: A status report. Am J Lifestyle Med 2015;12(1):4-20. https://doi.org/10.1177/1559827615619159 